\title{
The Effect of Relational Resources on Thriving at Work: The Role of Agentic Behaviors and Ability to Manage Resources
}

\author{
Yi Yang ${ }^{1, *}$, Yanfeng Mao ${ }^{1}$, Tianqi Leng ${ }^{2}$ \\ ${ }^{1}$ Business School of Hunan Normal University, People's Republic of China \\ ${ }^{2}$ China Machinery International Engineering Design \& Research Institute Co., Ltd. \\ *Corresponding author. Email: 942179817@qq.com
}

\begin{abstract}
Developing and maintaining thriving at work is an important way to realize personal value and improve organizational performance. Based on the Conservation of Resources Theory, we proposed and tested the mediation model of relational resources affecting thriving at work. Empirical data of 271 employees showed that relational resources directly predicted the thriving at work, colleague trust and supervisor support influenced each other, which through agentic behaviors (task focus and heedful relating), thus formed four chain intermediary paths that affected thriving at work in sequence. The moderating effect of the ability to manage resource occurred in the first half of the intermediary path, which positively moderated the influence of relational resources on agentic behaviors. The study had enhanced the understanding of the internal mechanism and boundary conditions of the relationship between relational resources and thriving at work, enriched the research on the mechanism of agentic behaviors, and provided a foundation for organizations to promote thriving at work.
\end{abstract}

Keywords: Relational Resources, Agentic Behaviors, Thriving at work, Ability to Manage Resource.

\section{INTRODUCTION}

In the era of knowledge economy, the complex and changing work environment has many negative impacts on individuals. For example, the uncivilized behavior in the workplace leads to the decline of employees' mental health, and the balance and contradiction between work and family reduce individuals' job satisfaction (Lim, Cortina, Magley, 2008; Perrewe, Hochwarter, Kiewitz, 1999)[1][2]. Thriving at work (TAW) is the mental state that employees are full of vitality and learning at work, and it is the positive adjustment and adaptation of individuals to the environment, which realizes the dialectical unity of self-development and organizational development (Spreitzer et al., 2005)[3]. Current research shows that TAW is not only conducive to the personal physical and mental health development of employees, but also has a significant impact on job performance, job satisfaction and innovative behaviors (Niessen et al., 2017; Walumbwa et al., 2018)[4][5]. Therefore, it is particularly important for managers to develop and maintain employees' TAW (Ashford, Caza, Reid, 2018)[6]. On the one hand, managers want employees to be full of vigour and vitality; on the other hand, they also want employees to keep learning and developing, so as to realize team goals through the realization of individual performance goals (Spreitzer, Porath, Gibson, 2012)[7] .

Relational resources are high-quality connections between individuals. Spreitzer et al. (2005)[3] described the promoting effect of relational resources on TAW through agentic behaviors in socially embedded model of TAW. We focused on two important types of relational resources:(1) the relationship between individuals and colleagues, that is, peer trust; (2) the relationship between leaders and individuals, namely, supervisor support. Existing literature has verified the influence of the above two kinds of relational resources on TAW. For example, Paterson[8] (2014) used 198 employee-supervisor pairing data to verify that superior support promoted TAW. Niessen[8] (2012) empirically tested the influence of team support (colleague trust) on TAW by using the method of daily research. But as far as we know, there is no paper put colleague trust and supervisor support on the same conceptual framework for empirical research, so we cannot accurately determine whether colleague trust and supervisor support are two independent variables in the impact on TAW, or whether and how this correlation 
plays a role. Secondly, there are inconsistent conclusions in the limited studies on the influence of relational resources on TAW. For example, the conclusions of Niessen (2012) did not support the hypothesis of the predictive effect of colleague trust on agentic behaviors. This may mean that there are some moderating variables that enhance, weaken or even change the relationship. Therefore, we not only need to pay attention to the relationship between relational resources and TAW, but also need to clarify the internal mechanism and boundary conditions for the occurrence of this relationship.

Based on Conservation of Resources Theory (COR) and self-determination theory, we proposed and verified a two-stage mediation model of the relational resources affecting TAW, which enriched current research from three aspects. Firstly, we examined the internal mechanism of relational resources to TAW, and found that the influence of colleague trust and supervisor support was not completely independent, they could not only directly predict TAW, caused and affected mutually, but also influenced TAW through agentic behaviors. These findings further extended Spreitzer's (2005) Socially Embedded Model of TAW and enhanced the understanding of resource linkage and priorities. Secondly, we also found that the positive behavioral effects of relational resources were regulated by ATMR, because having resources did not mean being able to use resources effectively. This partly explained the reasons why individual behaviors were different in social context, enriched the occurrence mechanism of agentic behaviors and the action mechanism of ATMR. Finally, we tested for the first time the relationship between job resources, agentic behaviors and TAW in the model of Spreitzer et al. (2005) by using Chinese data. The findings supported the mechanism of the influence of relational resources on TAW, which was helpful to enrich the cross-cultural research on the theory of TAW.

\section{THEORETICAL AND HYPOTHESIS}

\subsection{Relational resources and TAW}

Relational resources are high-quality connections or ties between individuals, which may be generated in the interaction with colleagues (mentors, friends, other department personnel, suppliers or customers). An individual's perception of resources at work is the basis of thriving (Spreitzer et al., 2005)[3]. Colleague trust is a positive state in which members of an organization or a team trust and depend on each other, which can promote employees' TAW (Parker, Williams, Turner, 2006)[10]. Firstly, as an important social resource, colleague trust is an important component of a positive work context, which can enhance individuals' perception of social support, reduce burnout, and maintain vitality (Halbesleben, Wheeler, 2012)[11]. Shraga and Shirom (2009)[11] found that support, trust, cooperation and warm relationships among colleagues were important reasons for individual vitality. Pearson and Porath (2005)[13] pointed out that high colleague trust was beneficial to the development of positive emotions and energize employees (Zhang Yanhong, Li Yongzhou, 2018)[14]. In addition, colleague trust endows individuals with courage and strength. When the individuals perceive higher level of colleague trust, the more an individual is trusted by his colleagues, the more relieved and enthusiastic about learning he will be $(\mathrm{Tu}$ Xingyong, Zhang Qi et al., 2017)[15]. The research of Lewicki (2006)[16] showed that colleague trust provided an open and inclusive environment for employees, since employees could actively discuss, communicate and practice new ideas frequently (Duden, 2012)[17]. Ferres (2004)[18] proposed that colleague trust helped employees to perceive organizational support, as well as a significant impact on employees' psychological security, self-efficacy and other cognition. Therefore, we propose that:

H1a: Colleague trust has a significant impact on TAW. The higher the colleague trust, the higher the level of TAW.

Supervisor support is a kind of prosocial motivation and behavior of leaders, and is the subjective perception of employees on the resources given by leaders (Frazier and Tupper, 2016)[19]. As well as colleague trust, supervisor support plays an important predictor of TAW. Firstly, TAW is a subjective experience, and supervisor support directly affects employees' perception and behaviors. Research conducted by Crant (2000)[20] showed that expectations and praise of employees from supervisor were effective motivators for employees to make continuous efforts ( $\mathrm{Li}$ et al., 2014)[21]. Paterson (2014)[8] also found that for employees, supervisor support was an important social capital that could promote TAW. Secondly, supervisor support endows employees with higher work autonomy which improves their learning initiative (Jaiswal et al.,2017; Li Lu, Ye Baojuan et al., 2019)[22][23]. Duden (2012)[17] found that supervisor support was not only a kind of contextual situation and atmosphere, but also an important basis for learning and development in the TAW (Li Chaoping, Mao Kaixian, 2018)[24]. Jaiswal[22] (2017) also argued that there was an important relationship between supervisor support and colleague trust, employee learning behavior. Finally, supervisor support gives people a higher sense of job security, which enables employees to have a higher organizational commitment, and enables employees to grow and develop with vigour (Walumbwa et al., 2016; Wang Rong, 2017)[25][26]. To sum up, we propose that:

H1b: Supervisor support is positively related to TAW. The higher the supervisor support, the higher the level of TAW. 


\subsection{Mediating effect of agentic behaviors}

As stated by Bandura[27] (2001), agentic behaviors were trivial, purposeful behaviors as a reflection of our daily working pattern (Sonenshein et al., 2013)[28]. Spreitzer et al. (2005) believed that agentic behaviors such as task focus, heedful relating and exploration were the engines of TAW and played an intermediary role between resources and prosperity (Han Ji and Wei Wenwen, 2013)[29]. Our research focused on two of these agentic behaviors: task focus and heedful relating.

Task focus mediates the relationship between colleague trust, supervisor support and TAW. Task focus refers to an individual's focus on activities related to the completion of job responsibilities. Individuals' emotional and cognitive abilities are different at work, while colleague trust and supervisor support can improve personal focus. Kahn (1990)[30] found that support, flexibility, clarity and effective interaction with managers created a safe and meaningful work environment that helped employees to improve their attention and focus on the completion of tasks. Supervisor support and colleague trust create a safe, supportive and attributional work environment, which can promote task-focused behaviors (Brown, Westbrook, Challagalla, 2005)[31]. Paterson (2014) [8]pointed out that high attention and engagement related to tasks could improve the probability of individuals successfully completing tasks, motivate individuals to learn the skills needed to complete tasks, bring high emotional benefits and sense of achievement, which made employees more likely to experience the TAW (Rothbard, 2001)[32]. We propose that:

$\mathrm{H} 2$ : Task focus mediates the relationship between relational resources and TAW.

Heedful relating is an individual's successful cooperation with others in a team and the conscious establishment of social relationships at work (Druskat and Pescosolido, 2002)[33]. Heedful relating mediates the relationship between colleague trust, supervisor support and TAW. Supervisor' support and colleagues' trust creates a social environment that focuses on the realization of goals of both themselves and others. Employees are more likely to put forward and contribute new ideas in the team, think more from the perspective of others, obey the unified rules of the team, and form a heedful relating with other members of the term (Spreitzer et al., 2005; Kahn, 1990)[3][30]. At the same time, according to Social Learning Theory, through interaction and communication with colleagues, individuals actively improve their skills, acquire new knowledge, and ultimately achieve a state of TAW (Bandura, 2001; Kark \& Carmeli, 2009)[27][34]. Atwater (2009) [35]found that the heedful relating between individuals and others provided opportunities for learning. Carmeli (2009) [36]proved that social support provided by supervisor could generate positive and heedful relating among individuals' social capital, thus promoting TAW[37][38]. We propose that:

H3: Heedful relating mediates the relationship between relational resources and TAW.

\subsection{Interaction of relational resources}

The related literature of COR has begun to focus on the relationship between resources. For example, the research of Schmidt and Keil (2013)[39] showed that some resources were strengthened only after other resources obtained. Individuals can increase the value of a new resource by knowing how well it matches an existing resource bundle. Halbesleben et al. (2014)[40] argued that future research should focus on exploring how to combine various resources to achieve goals. Therefore, we believe that there is also some form of correlation between the two kinds of relational resources: colleague trust and supervisor support. Boies et al.[41] (2015) pointed out that leadership style had an important influence on team trust. An empirical study from Zhang and Tsui (2008)[42] showed that supervisor support played an important role in promoting trust among middle managers. Since supervisors are people who directly evaluate the performance of an employee, the autonomy of an employee's work is also significantly related to the supervisor management style (Bono et al.,2007)[43]. Supervisor support can make employees feel that they are trusted, so employees are more willing to trust each other between work teams and colleagues and cooperate to achieve goals. At the same time, good interpersonal trust is beneficial to the exchange relationship between leaders and employees, so as to realize the relational leadership that supports employees' development (Brower, Schoorman, Tan, 2000)[44].

H4a: Supervisor support can promote colleague trust

H4b: Colleague trust can promote supervisor support

\subsection{Moderating effect of ATMR}

According to the COR, the ATMR refers to individuals' self-perception of the resources they own and their self-cognition of whether they can effectively use relevant resources based on their own unique resource bundle (Hobfoll,1989; Hobfoll et al., 2003)[45][46]. Individuals with strong ATMR can not only effectively use all kinds of resources at work, but also bear the consumption of resources by various activities to avoid the exhaustion of personal resources. (Brouer, Gallagher, Badawy, 2015; Hochwarter, Laird, Brouer, 2007)[47][48].

The moderating effect of ability to manage resource on relational resources and agentic behaviors can be explained by COR. COR reveals that individuals need to 
protect existing resources and acquire new valuable resources through effective resource investment behavior (Hobfoll et al., 2003)[46]. Since individuals' resources are limited., they will make active resource investment in order to prevent resource loss and obtain new valuable resources (Hobfoll, 1989)[45]. Hobfoll et al. (2003) pointed out that individuals in the initial resource bundle advantage position, that is, individuals with more valuable resources, were more willing to invest resources. Compared with individuals with weak ability to manage resource, those with strong abilities are more able to effectively utilize the two relational resources, namely, colleague trust and supervisor support, who will increase the investment of agentic behaviors in task focus and heedful relating. Therefore, individuals with strong ability to manage resource are more able to effectively use relational resources and implement agentic behaviors.

The moderating effect of the ability to manage resource on agentic behaviors and TAW can also be explained by COR (Hobfoll, 1989)[45]. In the process of agentic behaviors, individuals need to maintain a high degree of focus and vigilance in work, which consumes some energy resources (such as time and energy), to some extent, which will reduce work vitality and weaken TAW (Dalal and Sheng, 2019)[49]. Ability to manage resource is the dialectical unity of an individual's subjective perception and actual executive ability, which plays a fundamental role in the balance between the gains and losses of work resources (Frieder, Hochwarter, Deortentiis, 2015)[50]. The resource profit and loss principle assert that individuals with more resources have better access to them, while individuals with fewer resources are more likely to experience resource loss (Hobfoll et al., 2003)[46]. Therefore, individuals with strong ability to manage resource can more easily obtain the benefits (like vitality and growth) brought by agentic behaviors, and effectively avoid the resource consumption brought by agentic behaviors. Some empirical research also preliminarily supports this view. The research of Brouer (2015) [47]showed that when individuals had high ATMR, they could effectively control the consumption of resources by work activities, prevented resource exhaustion, and at the same time helped to increase the income of resources. Hochwarter(2007) [48]found that individuals with strong ability to manage resource could make better use of existing resources to regulate personal behaviors, and could more successfully meet various requirements in different environments. Therefore, we propose that:

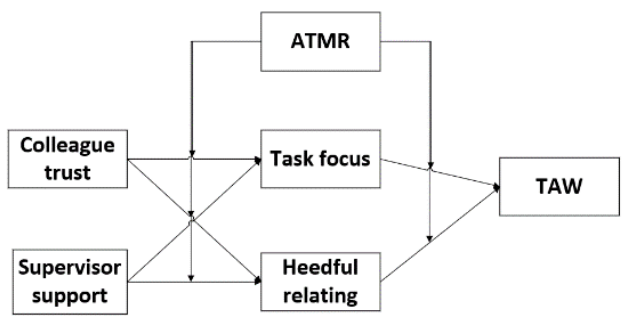

Figure 1 Research theoretical model

H5: ATMR plays a moderating role between relational resources and agentic behaviors. The stronger ability to manage resource is, the greater influence of a) colleague trust, b) supervisor support on agentic behaviors is.

H6: ATMR plays a moderating role between agentic behaviors and TAW. The stronger ATMR, the stronger agentic behaviors a) task focus, b) heedful relating, contribute to TAW.

To sum up, the theoretical model of this paper is shown in Figure 1.

\section{METHODOLOGY}

\subsection{Sample}

This study is a part of the project of "Research on the Work Behavior and Performance of Technical Talents in High-tech Enterprises". In September 2018, we distributed questionnaires to enterprises in the national high-tech zones in Hunan and Guangdong provinces. The questionnaire of this study contained scales of personal basic situation, colleague trust, supervisor support, task focus, heedful relating, TAW and ability to manage resource. 350 questionnaires were sent out and 342 were recovered with a recovery rate of $97.71 \%$. Excluded incomplete questionnaires, there were 271 valid questionnaires left with an effective rate of $77.43 \%$. Among the effective samples, 111 were males, accounting for $40.96 \%$, and 160 were females, accounting for $59.04 \%$. All of them were aged between 22 and 55 years, with an average age of about 29 years old, among which 22-35 years old accounted for the largest proportion (84.13\%), accounting for 228 persons. In terms of educational background, 158 samples had bachelor's degree, accounting for 58.31\%; 96 samples had master's degree, accounting for $35.42 \%$; 17 samples had doctor's degree, accounting for $6.27 \%$; In terms of positions, there were 204 grass-roots employees, accounting for $75.28 \%, 23$ department directors, accounting for $8.49 \%, 32$ middle-level leaders of the department, accounting for $11.81 \%$, and 12 high-level leaders of the department, accounting for $4.42 \%$. 


\subsection{Measurement}

We used empirically tested mature scales at home and abroad for measurement, all of which were Likert fivepoint scale. The interpersonal trust scale adapted by Parker (2006) [51] was adopted for colleague trust, with a total of 4 items; for example, our team members have strong mutual trust. The Cronbach's $\alpha$ coefficient of the scale was 0.904. Supervisor support adopted the Leadership Support Scale adapted by Parker (2006)[51], consisting of four items. For example, leaders encourage us to have high expectations of ourselves, and the Cronbach's $\alpha$ coefficient of the scale was 0.911 . Task focus adopted the Task Focus Scale adapted by Rothbard[52] (2001), consisting of 3 items, such as I am fully engaged in my work. The Cronbach's $\alpha$ coefficient of the scale was 0.906 . The heedful relating scale adapted by Daniel (2015)[53] was adopted, with a total of 3 items, for example, I try to think about how to combine my ideas with those of other team members. Cronbach's $\alpha$ coefficient of the scale was 0.866. The ATMR adopted the scale developed by Hochwarter (2007)[54], consisting of 6 items, for example, I can grasp the pace of work even if the work is complicated. And the Cronbach's $\alpha$ coefficient of the scale was 0.874 . The measurement of TAW adapted the scale developed by Porath et al. (2012)[55]. The scale is divided into two dimensions, consisting of 8 items. The learning dimension is measured by the first 4 items, such as I am active in learning; the vitality dimension is measured by the last 4 items, such as I am full of energy and energy. Cronbach's $\alpha$ coefficient of the scale was 0.925 .

\subsection{Control variables}

We controlled for a number of demographic characteristics associated with TAW, such as gender, age, education level, management level, and in the analysis, age and tenure were directly input; Gender was input as dummy variable. 0 represented male and 1 represented female. The education level was coded, with 1-4 representing junior college, bachelor's degree, master's degree and doctor's degree. The code of management level was $1-4$, which respectively represented the senior level of the company, the middle level of the department, the department director and the ordinary staff.

\section{DATA ANALYSIS AND HYPOTHESIS TESTING}

SPSS22.0 and MPLUS 7.4 were used for statistical analysis. Firstly, confirmatory factor analysis was performed on all variables to determine the validity of the variable measurements, and descriptive statistics and correlation analysis were performed on the variables. Secondly, the hypothesis model was tested. The structural equation model (SEM) was used to investigate the relationships among colleague trust, supervisor support, task focus, heedful relating, TAW, and ATMR. Bootstrap was used to analyse the mediating effects of task focus and heedful relating on colleague trust, supervisor support, and TAW. Finally, the moderating effect of ability to manage resources was further analysed, the path model was verified, and the influence path of relational resources on TAW was analysed by additional chain-mediated analysis.

\subsection{Analysis of common method deviation and validity}

Since all the questionnaire data came from employees' self-reports, there was a risk of common method deviation. Therefore, we used two different methods for testing. According to Harman's single-factor test method, in the single-factor model, $\mathrm{X} 2 / \mathrm{DF}=8.67$, RMSEA $=0.168, \mathrm{CFI}=0.540, \mathrm{TLI}=0.503, \mathrm{SRMR}=0.122$, and all the fitting indexes were not ideal, which proved that the deviation of the common method in this study was not prominent to a certain extent. Considering that all variables were latent variables, Harman's single-factor test method was more often used to test the severity of the deviation of the common method, and its sensitivity was limited in the test. Then, we used the unmeasurable latent factor model to test. This method was proposed by Anderson and Williams in 1998, mainly by building the method deviation into an unmeasurable latent variable input model, and comparing the fitting results with the final model (Anderson, West, 1998). The test results were shown in Table 1. After a latent variable of common method deviation was added to the six-factor model, the measured values of each fitting index changed within 0.01 , which proved that the addition of this variable had a poor improvement effect on the model, namely, there was no serious common method deviation. Meanwhile, Table 1 showed that the six-factor model had the minimum RMSEA and SRMR, the CFI value was 0.928 , the TLI value was 0.918 , and the fitting degree was optimal. Compared with other models, the variables had good discriminative validity, and the latent variables used have good convergence validity, which proved that the data could be used to effectively measure the model. 
Table 1. Confirmatory factor analysis results

\begin{tabular}{ccccccc}
\hline Model & $\mathrm{X}^{2}$ & $\mathrm{df}$ & RMSEA & CFI & TLI & SRMR \\
\hline $\begin{array}{c}\text { Six-factor model } \\
\text { Unmeasurable latent factor } \\
\text { model }\end{array}$ & 750.080 & 330 & 0.069 & 0.928 & 0.918 & 0.058 \\
Five-factor model & 738.417 & 337 & 0.066 & 0.931 & 0.923 & 0.061 \\
Four-factor model & 1127.893 & 339 & 0.093 & 0.865 & 0.849 & 0.061 \\
Three-factor model & 1497.901 & 343 & 0.111 & 0.802 & 0.782 & 0.090 \\
Two-factor model & 1697.603 & 346 & 0.120 & 0.768 & 0.747 & 0.075 \\
Single factor model & 2297.620 & 348 & 0.144 & 0.666 & 0.637 & 0.134 \\
\hline
\end{tabular}

Note: CT: colleague trust; SS: Supervisor support; Ability to manage resources: ATMR; TF: task focus; HR: Heedful relating; TAW: Thriving at work; Single factor: CT+SS +ATMR+TF+HR+TAW; CT+SS+ATMR, TF+HR+TAW; Three factors: CT+SS, ATMR+TF+HR, TAW; Four factors: CT+SS, ATMR, TF+HR, TAW; Five factors: CT+SS, ATMR, TF, HR, TAW; Six factors: CT, SS, ATMR, TF, HR, TAW;

\subsection{Describes statistical and correlation analyses}

The results of descriptive statistics and correlation analysis were shown in Table 2, and (1) colleague trust $(\mathrm{r}=0.473, \mathrm{P}<0.01)$ and supervisor support $(\mathrm{r}=0.429, \mathrm{P}$ $<0.01)$ were significantly positively correlated with TAW; (2) Colleague trust $(\mathrm{r}=0.450, \mathrm{P}<0.01)$ and supervisor support ( $\mathrm{r}=0.435, \mathrm{P}<0.01)$ were significantly positively correlated with task focus;(3) Colleague trust $(\mathrm{r}=0.516, \mathrm{P}<0.01)$, supervisor support $(\mathrm{r}=0.449, \mathrm{P}<0.01)$ were significantly positively correlated with heedful relating; $; 4)$ Task focus $(\mathrm{r}=0.639, \mathrm{P}<0.01)$ and heedful relating $(\mathrm{r}=0.440, \mathrm{P}<0.01)$ were significantly positively correlated with TAW ; 5 ATMR $(r=0.620, \mathrm{P}<0.01)$ was significantly positively correlated with TAW.

Table 2. Variable description statistics and correlation analysis

\begin{tabular}{|c|c|c|c|c|c|c|c|c|c|c|c|c|c|}
\hline Variable & M & $S D$ & 1 & 2 & 3 & 4 & 5 & 6 & 7 & 8 & 9 & 10 & 11 \\
\hline Gender & 1.59 & 0.49 & 1 & & & & & & & & & & \\
\hline Age & 29.14 & 6.09 & $-.132^{*}$ & 1 & & & & & & & & & \\
\hline $\begin{array}{l}\text { Education } \\
\text { background }\end{array}$ & 3.47 & 0.61 & -.063 & $206^{* *}$ & 1 & & & & & & & & \\
\hline $\begin{array}{c}\text { Management } \\
\text { level }\end{array}$ & 3.54 & 0.86 & $.159^{\star *}$ & $-.383^{* *}$ & .116 & 1 & & & & & & & \\
\hline Tenure & 5.17 & 4.69 & $-.163^{* *}$ & $.642^{\star *}$ & .100 & $-.324 \star *$ & 1 & & & & & & \\
\hline $\begin{array}{c}\text { Colleague } \\
\text { trust }\end{array}$ & 3.68 & 0.78 & -.075 & -.014 & -.045 & $-.185^{\star *}$ & -055 & $\begin{array}{c}1 \\
(0.905)\end{array}$ & & & & & \\
\hline $\begin{array}{l}\text { Supervisor } \\
\text { support }\end{array}$ & 3.60 & 0.80 & $-.132^{\star}$ & .028 & .038 & $-.187^{\star *}$ & .007 & $.636^{* *}$ & $\begin{array}{c}1 \\
(0.912)\end{array}$ & & & & \\
\hline ATMR & 3.39 & 0.79 & $-.209 * *$ & .064 & .058 & $-.240^{\star *}$ & $.153^{\star}$ & $.524^{\star *}$ & $.439^{* *}$ & $\begin{array}{c}1 \\
(0.861)\end{array}$ & & & \\
\hline Task focus & 3.22 & 0.95 & $-.165^{\star *}$ & $-126^{*}$ & $-154^{*}$ & $-.229^{* *}$ & .051 & $-450^{* *}$ & $.435^{\star *}$ & $.541^{* *}$ & $\begin{array}{c}1 \\
(0.912)\end{array}$ & & \\
\hline $\begin{array}{l}\text { Heedful } \\
\text { relating }\end{array}$ & 3.91 & 0.72 & -.097 & .000 & .044 & $-.235^{\star \star}$ & .110 & $.516^{* *}$ & $.449^{* *}$ & $.533^{\star *}$ & $-401^{* *}$ & $\begin{array}{c}1 \\
(0.875)\end{array}$ & \\
\hline TAW & 3.50 & 0.77 & $-.220 * *$ & $-130^{*}$ & $-140^{*}$ & $-.254^{\star *}$ & $.136^{*}$ & $-473^{* *}$ & $.429^{* *}$ & $620^{* *}$ & $.639^{* *}$ & $.440^{* *}$ & $\begin{array}{c}1 \\
(0.920)\end{array}$ \\
\hline
\end{tabular}

Note: $\mathrm{N}=271$, * means $\mathrm{P}<0.05$, ** means $\mathrm{P}<0.01$. The numbers in () represent the combined reliability of the corresponding latent measurement 


\subsection{Hypothesis test}

\subsubsection{Test of main effects of relational resources on TAW}

Firstly, SEM was used to test Hypothesis 1. After controlling for age, gender, education background, management level and tenure, colleague trust $(\beta=0.402$, $\mathrm{P}<0.001)$ had a significant effect on TAW. Supervisor support $(\beta=0.426, \mathrm{P}<0.001)$ had a significant impact on TAW. The fitting indexes of the SEM of the main effect of the model were shown as M1 and M2 in Table 3. The model fitted well, and Hypothesis 1 was valid.

Table 3. Model hypothesis testing

\begin{tabular}{ccccccc}
\hline & & \multicolumn{5}{c}{ Dependent Variable: TAW } \\
Variable & M1 & M2 & M3 & M4 & M5 & M6 \\
\hline Gender & $-0.161^{*}$ & $-0.168^{*}$ & $-0.100^{*}$ & $-0.140^{*}$ & -0.088 & $-0.118^{*}$ \\
Age & -0.023 & -0.004 & -0.057 & 0.058 & -0.064 & 0.050 \\
Education background & 0.089 & 0.078 & -0.017 & 0.039 & -0.018 & 0.029 \\
Management level & $-0.162^{*}$ & $-0.015^{*}$ & -0.084 & -0.115 & -0.077 & -0.107 \\
Tenure & 0.082 & 0.013 & 0.099 & 0.020 & 0.108 & 0.037 \\
Colleague trust & $0.402^{* *}$ & & $0.117^{*}$ & $0.191^{*}$ & & \\
Supervisor support & & $0.426^{* *}$ & & & $0.156^{* *}$ & $0.259^{* *}$ \\
Task focus & & & $0.624^{* *}$ & & $0.606^{* *}$ & \\
Heedful relating & & & & $0.390^{* *}$ & & $0.372^{* *}$ \\
X /df & 2.05 & 2.17 & 2.66 & 2.37 & 2.57 & 2.61 \\
CFI & 0.956 & 0.955 & 0.921 & 0.930 & 0.926 & 0.918 \\
TLI & 0.946 & 0.944 & 0.907 & 0.917 & 0.914 & 0.904 \\
RMSEA & 0.062 & 0.064 & 0.078 & 0.071 & 0.076 & 0.077 \\
SRMR & 0.047 & 0.051 & 0.073 & 0.057 & 0.074 & 0.062 \\
\hline
\end{tabular}

Note: $\mathrm{N}=271, *$ means $\mathrm{P}<0.05, * *$ means $\mathrm{P}<0.01$

\subsubsection{Mediating effect analysis of agentic behaviors}

SEM was used to test the mediating effect of agentic behaviors in Hypothesis 2 and Hypothesis 3.There were significant correlations between colleague trust and task focus $(\beta=0.576, \quad P<0.001)$, and heedful relating $(\beta=0.575, \quad P<0.001)$, The relationship between supervisor support and task focus $(\beta=0.466, \mathrm{P}<0.001)$ was significant and heedful relating $(\beta=0.486, \mathrm{P}<0.001)$. Colleague trust had a significant positive effect on task focus $(\beta=0.473, P<0.001)$ and heedful relating $(\beta=0.587$, $\mathrm{P}<0.001)$. Task focus $(\beta=0.624, \mathrm{P}<0.001)$ and heedful relating $(\beta=0.390, \mathrm{P}<0.001)$ had a significant positive effect on TAW. Supervisor support had a significant positive effect on task focus $(\beta=0.478, \mathrm{P}<0.001)$ and heedful relating $(\beta=0.498, P<0.001)$, and task focus $(\beta=0.606, \mathrm{P}<0.001)$ and heedful relating $(\beta=0.372, \mathrm{P}$ $<0.01)$ to TAW. The fitting indexes of the model were well, and the mediating effect hypothesis of Hypothesis 2 and Hypothesis 3 was verified. 
In addition, MPLUS 7.4 was used to set Bootstrap to 2000 for sampling, and the mediating effect path analysis results were shown in Table 4.The four mediating path coefficients were all positive, and the upper and lower limits of $95 \%$ confidence intervals did not contain 0 , which proved that both colleague trust and supervisor support could positively promote TAW through agentic behaviors, and the influence of colleague trust was slightly greater than that of supervisor support, again supporting Hypothesis 2 and Hypothesis 3.

Table 4. Path coefficient of mediating effect

\begin{tabular}{|c|c|c|c|}
\hline \multirow{2}{*}{ Intermediary path } & \multirow{2}{*}{$\begin{array}{c}\text { Point estimate } \\
\text { (standardization) }\end{array}$} & \multicolumn{2}{|c|}{$95 \%$ confidence interval } \\
\hline & & Upper limit & Lower limit \\
\hline Colleague trust $\rightarrow$ Task focus $\rightarrow$ TAW & 0.296 & 0.222 & 0.387 \\
\hline Colleague trust $\rightarrow$ Heedful relating $\rightarrow$ TAW & 0.228 & 0.130 & 0.337 \\
\hline Supervisor support $\rightarrow$ Task focus $\rightarrow$ TAW & 0.290 & 0.205 & 0.388 \\
\hline Supervisor support $\rightarrow$ Heedful relating $\rightarrow$ TAW & 0.180 & 0.106 & 0.279 \\
\hline
\end{tabular}

Note: $\mathrm{N}=271, *$ means $\mathrm{P}<0.05$, ** means $\mathrm{P}<0.01$

\subsubsection{Interaction test of relational resources}

Firstly, we examined the interaction effect between colleague trust and supervisor support, but the results showed that the interaction term had no significant effect on TAW ( $\beta=-0.116, p>0.05)$. Next, we separately tested the standardized coefficients of colleague trust to supervisor support $(\beta=0.793, \mathrm{P}<0.001)$ and supervisor support to colleague trust $(\beta=0.788, \mathrm{P}<0.001)$, and then tested the chain mediating effect starting from colleague

Table 5. Chain mediating effect path coefficient trust and supervisor support through Bootstrap. As shown in Table 5, colleague trust and supervisor support could not only directly affect the TAW, but also correlated with each other and influenced each other sequentially. Specifically, colleague trust could influence agentic behaviors through supervisor support and predicted TAW. Similarly, supervisor support could influence agentic behaviors through colleague trust and predicted TAW, hypotheses $4 \mathrm{a}$ and $4 \mathrm{~b}$ were true.

\begin{tabular}{cccc}
\hline Intermediary path & Point estimate & \multicolumn{2}{c}{$95 \%$ confidence interval } \\
(standardization $)$ & Upper limit & Lower limit \\
\hline $\begin{array}{c}\text { Colleague trust } \rightarrow \text { Supervisor support } \rightarrow \text { Task focus } \rightarrow \text { TAW } \\
\text { Colleague trust } \rightarrow \text { Supervisor support } \rightarrow \text { Heedful } \\
\text { relating } \rightarrow \text { TAW }\end{array}$ & 0.229 & 0.316 & 0.162 \\
$\begin{array}{c}\text { Supervisor support } \rightarrow \text { Colleague trust } \rightarrow \text { Task focus } \rightarrow \text { TAW } \\
\text { Supervisor support } \rightarrow \text { Colleague trust } \rightarrow \text { Heedful } \\
\text { relating } \rightarrow \text { TAW }\end{array}$ & 0.147 & 0.242 & 0.078 \\
\hline
\end{tabular}

Note: $\mathrm{N}=271, *$ means $\mathrm{P}<0.05, * *$ means $\mathrm{P}<0.01$ 


\subsubsection{The moderating effect test of ATMR}

We examined: (1) the effects of colleague trust, supervisor support and their interaction with ATMR on task focus and heedful relating;(2) The effects of task focus, heedful relating and their interaction with ATMR on TAW. Except for the interaction effect, both (1) and (2) had been preliminarily verified in the mediation test. The effect of each interaction item was supplemented here. The results showed that the interaction between Table 6. Moderating effect path coefficient colleague trust and ATMR to task focus $(\beta=0.203$, P $<0.05)$ and heedful relating $(\beta=0.157, \mathrm{P}<0.05)$ were significant, while the interaction between supervisor support and to task focus $(\beta=0.252, \mathrm{P}<0.05)$ and heedful relating $(\beta=0.180, \mathrm{P}<0.05)$ were significant, but the interaction between task focus and ATMR ( $\beta=0.031, \mathrm{P}$ $>0.05)$, heedful relating and ATMR $(\beta=-0.065, \mathrm{P}>0.05)$ and TAW was not significantly affected. Specific regulatory effects are shown in Table 6.

\begin{tabular}{cccccc}
\hline $\begin{array}{c}\text { Dependent } \\
\text { Variable }\end{array}$ & Interactive item & $\begin{array}{c}\text { Point estimate } \\
\text { (standardization } \\
\text { ) }\end{array}$ & S.E. & Lower limit & Upper limit \\
\hline Task focus & $\begin{array}{c}\text { Colleague trust *ATMR } \\
\text { Supervisor support } \\
\text { *ATMR }\end{array}$ & 0.170 & 0.101 & 0.336 & 0.004 \\
$\begin{array}{c}\text { Heedful } \\
\text { relating }\end{array}$ & $\begin{array}{c}\text { Colleague trust *ATMR } \\
\quad \begin{array}{c}\text { Supervisor } \\
\text { support*ATMR }\end{array}\end{array}$ & 0.211 & 0.113 & 0.397 & 0.025 \\
\hline
\end{tabular}
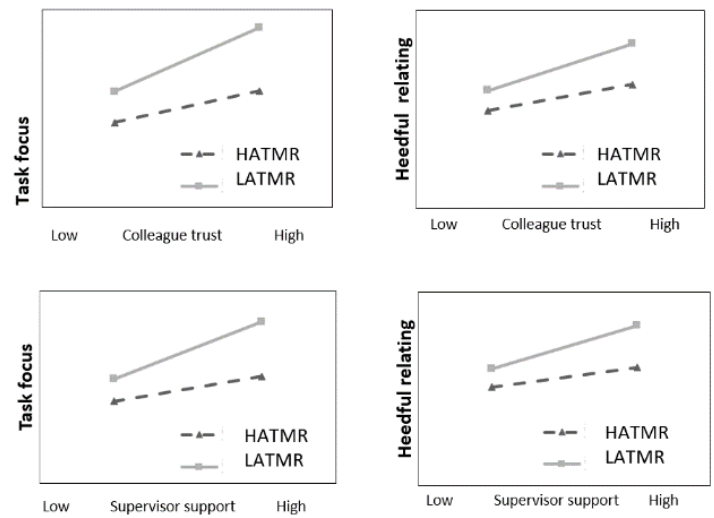

Figure 2 The moderating effect of ATMR on relational resources and agentic behaviors

Therefore, it could be concluded that ATMR regulated the relationship between relational resources and agentic behaviors, but did not significantly regulate the relationship between agentic behaviors and TAW. Hypothesis 5 was true, but Hypothesis 6 was not supported. The verified model was the mediated model.
The moderating effect of ATMR on relational resources and agentic behaviors was shown in Figure 2.

\section{CONCLUSION AND DISCUSSION}

\subsection{Conclusions and contributions}

Firstly, our findings supported the description of relational resources and TAW by Spreitzer et al.[3] (2005). We found that colleague trust and supervisor support had significantly positive effects on agentic behaviors (task focus and heedful relating) and TAW respectively. Agentic behaviors had significant positive effects on TAW, and agentic behaviors was an important mediating variable between relational resources and TAW.

Secondly, the moderating effect of ATMR occurs in the first half of the influence path of relational resources $\rightarrow \mathrm{TAW}$, that is, the stronger the ATMR was, the greater the influence of relational resources on agentic behaviors. This result partly explained why the prediction effect of 
relational resources on agentic behaviors in the study of Niessen (2012) [8]was not significant. ATMR strengthened the internal motivation of agentic behaviors. Employees with strong abilities had better expectation of behavioral results and could effectively measure and use relational resources such as colleague trust and supervisor support. On the contrary, employees with weak ATMR might consciously control or avoid the occurrence of agentic behaviors. However, our analysis data did not confirm the moderating effect of ATMR between agentic behaviors and TAW, possibly because agentic behaviors was a kind of behavior driven by strong intrinsic motivation to experience TAW (Spreitzer et al., 2005)[3]. Individuals might claim to experience TAW even if the behavior consumed resources, and our data might fail to capture the actual thriving of employees.

Finally, in the additional analysis, we found that there was a sequential influence relationship between colleague trust and supervisor support, which, together with agentic behaviors, formed a chain-like mediating path that affects TAW. Colleague trust $\rightarrow$ Supervisor support $\rightarrow$ Task focus $\rightarrow$ TAW, Colleague trust $\rightarrow$ Supervisor support $\rightarrow$ Heedful relating $\rightarrow$ TAW, Supervisor support $\rightarrow$ Colleague trust $\rightarrow$ Task focus $\rightarrow$ TAW, Supervisor support $\rightarrow$ Colleague trust $\rightarrow$ Heedful relating $\rightarrow$ TAW, the four chain intermediary path effect were significantly. COR maintains that resources exist in the form of resource caravans, and caravans represents a resource pattern that usually occurs together. For example, people with high self-efficacy tend to be optimistic (Hobfoll, 2003)[46]. This means that when we analyse resources in a conceptual model, not only should we do independent analysis, but also we have to consider the order in which these resources are placed and how they are combined to affect the goal. Based on the socially embedded model of TAW proposed by Spritzer et al. (2005)[3], the job resources that promote thriving include not only relational resources, but also knowledge, positive meaning and positive emotion resources. We strongly suggested that future studies should explore more resource linkage patterns and their influencing mechanisms.

In conclusion, we constructed and tested the mediation model of relationship resources influencing TAW. As far as we know, this was the first time that colleague trust and supervisor support were included in a unified conceptual framework for discussion, the first time that ATMR was taken as a boundary condition in social nested model (Spritzer et al.,2005)[3], and the first time that the relationship among resources, agentic behaviors and TAW was tested using Chinese employee data. This research had developed the direct effect, correlation effect, mediation effect and moderating effect mechanism of relational resources influencing TAW, which further enriched the generation mechanism of TAW, resource connection mode, the determination mechanism of agentic behaviors, and the influence mechanism of ATMR, and also made a certain contribution to the positive organizational behavior research.

\subsection{Practical implication}

First of all, managers should be aware that TAW is a positive psychological state, which is an important factor influencing the personal development of employees and the achievement of organizational goals. We encourage managers to enrich and enhance the resource pool of employees, enhancing individual task focus, promote high-quality relationships among individuals to develop and maintain employee TAW. Specifically, one is to encourage communication, interaction and cooperation among employees by means of building project team, group discussion and team-based rewards, so as to build a good trust relationship among colleagues. Second, managers should encourage and support employees' behaviors and ideas, and provide necessary human, material, financial and other resources for the completion of employees' work tasks. Furthermore, managers should evaluate and develop employees' ATMR scientifically and effectively. ATMR can be included in the recruitment standard and qualification requirements. The sense of self-efficacy and self-consciousness of employees can be cultivated through the use of authorized management in work, make employees feel that they have the ability to manage and control the resources needed to complete the task, and continue to stimulate the motivation of positive behavior of employees. Finally, by comprehensively considering organizational development and employee career development planning, organizations can provide more training opportunities to meet the learning and development needs of employees, seek common interests of employees and organizations, and enable employees to realize continuous learning and development at work, thus forming a virtuous cycle mechanism of TAW.

\subsection{Limitations and prospects}

Although the study had reached some enlightening conclusions, there were still some technical and theoretical shortcomings :(1) since we used crosssectional data, reverse causality between variables could not be excluded. Previous studies had proved the temporal fluctuation of TAW (Niessen et al., 2017)[4]. Future studies can adopt longitudinal follow-up studies to better grasp the causal or reciprocal relationship between variables. (2) The data of all variables were from employees' self-reports. Although the analysis results excluded the influence of common method bias, we suggested that future research could use the combination of self-assessment and other assessment to collect data, 
so as to further improve the reliability and validity of the research. (3) The study only considered a moderator variable, that is, ATMR, actually there might be multiple boundary conditions in relational resources and TAW, such as proactive personality, Big Five personality, and other stable personality traits. Cultural context variables such as individualism/collectivism and power distance may change the intensity and direction of the role of relational resources. In particular, we only used Chinese employee data to test Spreitzer's (2005) description, and we encouraged other scholars to conduct similar studies in different countries and regions to examine the crosscultural consistency or difference of the socially embedded model of TAW.

\section{FUNDING}

This study was supported by the National Natural Science Foundation of China (Grant No.71702055)

\section{REFERENCES}

[1] Lim, S., Cortina, L. M., \& Magley, V. J. Personal a nd workgroup incivility: Impact on work and healt $\mathrm{h}$ outcomes. Proceedings of the Journal of Applied Psychology(JAP), vol.93,APA Psyc Articles, Unite d States, 2008, pp.95-107. DOI: https://doi.org/10. 1037/0021-9010.93.1.95.

[2] Perrewe, P.L., Hochwarter, W.A., Kiewitz, C. Valu e attainment: An explanation for the negative effect s of work-family conflict on job and life satisfactio n. Proceedings of the Journal of Occupational Heal th Psychology, APA Psyc Articles, United States, 1 999, pp.318326.DOI: https://doi.org/10.1037/10768998.4.4.318.

[3] Spreitzer, G., Sutcliffe, K., Dutton, J., et al. A Soci ally Embedded Model of Thriving at Work. Procee dings of the Organization Science, vo1.6, INFORM S,2005, pp:537-549. DOI: https://doi.org/10.1287/o rsc. 1050.0153 .

[4] Niessen, C., Mäder, I., Stride, C., et al. Thriving w hen exhausted: The role of perceived transformatio nal leadership. Proceedings of the Journal of Vocat ional Behavior, ELSEVIER, vol.103,Netherlands,2 017,pp. 41-51. DOI: https://doi.org/10.1016/j.jvb.2 017.07.012.

[5] Walumbwa, F.O., Muchiri, M.K., Misati, E., et al. I nspired to perform: A multilevel investigation of an tecedents and consequences of thriving at work. $\mathrm{Pr}$ oceedings of the Journal of Organizational Behavio r, vol.39, WILEY, United States, New York City,2 018, pp. 249-261. DOI:https://doi.org/10.1002/job. 2216.

[6] Ashford, S.J., Caza, B.B., Reid, E.M. From survivi ng to thriving in the gig economy: A research agen da for individuals in the new world of work. Procee dings of the Research in Organizational Behavior, vol,38, ELSEVIER, Netherlands 2018, pp. 23-41. DOI:https://doi.org/10.1016/j.riob.2018.11.001.

[7] Spreitzer, G., Porath, C.L., Gibson, C.B. Toward h uman sustainability. Proceedings of the Organizati onal Dynamics, vol.41,2012, pp. 155-162.

[8] Paterson, T.A., Luthans, F., Jeung, W. Thriving at work: Impact of psychological capital and supervis or support. Proceedings of the Journal of Organizat ional Behavior, vol.35, WILEY, United States, Ne w York City 2014, pp. 434-446.DOI: https://doi.or g/10.1002/job.1907.

[9] Niessen, C., Sonnentag, S., Sach, F. Thriving at wo rk-A diary study. Proceedings of the Journal of O rganizational Behavior, vol.33, WILEY, United Sta tes New York City 2012, pp. 468-487. DOI: https:/ /doi.org/10.1002/job.763.

[10] Parker, S.K., Williams, H.M., Turner, N. Modellin $\mathrm{g}$ the antecedents of proactive behavior at work. $\mathrm{Pr}$ oceedings of the Journal of Applied Psychology, vo 1.91, APA Psyc Articles, United States 2006, pp. 63 6-652.DOI: https://doi.org/10.1037/t09103-000.

[11] Halbesleben, J.R.B., Wheeler, A.R. To Invest or N ot? The Role of Coworker Support and Trust in Da ily Reciprocal Gain Spirals of Helping Behavior. $\mathrm{P}$ roceedings of the Journal of Management, SAGE $\mathrm{j}$ ournals, vol.41,United States 2012, pp. 1628-1650. DOI:https://doi.org/10.1177/0149206312455246.

[12] Shraga, O., Shirom, A. The construct validity of vi gor and its antecedents: A qualitative study. Procee dings of the Human Relations, vol.62, SAGE journ als, United States ,2009, pp. 271-291.DOI: https://d oi.org/10.1177/0018726708100360

[13] Pearson, C.M., Porath, C.L. On the nature, consequ ences and remedies of workplace incivility: No tim e for "nice"? Think again. Proceedings of the Acad emy of Management Perspectives, vol.19,2005, pp. 7-18.DOI: https://doi.org/10.5465/ame.2005.1584 1946

[14] Zhang Yanhong, Li Yongzhou, Zhou Yong. The pr ocess mechanism of new employee organization so cialization from the perspective of relational resour ces. Proceedings of the Advances in Psychological Science, vol.26, 2018, pp.584-598(In Chinese).

[15] Tu Xingyong, Zhang Qi, Wang Zeying et al. Trust atmosphere, insider identity perception and employ ee in-role performance: The moderating effect of $m$ ediation. Proceedings of the Journal of psychology, vol.49, 2017, pp.83-93(In Chinese). 
[16] Lewicki, R.J., Gillespie, E.C. Models of interperso nal trust development Theoretical approaches, emp irical evidence and future directions. Proceedings o $\mathrm{f}$ the Journal of Management, vol.32, SAGE journa ls, United States 2006, pp. 991-1021.DOI: https://d oi.org/10.1177/0149206306294405.

[17] Duden, A. Trust in Learning Organizations. Procee dings of the International Journal of Management $\mathrm{C}$ ases, Ingentaconta, vol.14, 2012, pp. 167-175.DOI: https://doi.org/10.5848/apbj.2012.00095.

[18] Ferres, N., Connell, J., Travaglione, A. Co-worker trust as a social catalyst for constructive employee attitudes. Proceedings of the Journal of Managerial Psychology, vol.19, Emerald, The United Kingdo m, 2004, pp. 608-622.DOI: https://doi.org/10.1108/ 02683940410551516.

[19] Frazier, M.L., Tupper, C. Supervisor Prosocial Mot ivation, Employee Thriving, and Helping Behavior : A Trickle-Down Model of Psychological Safety. Proceedings of the Group \& Organization Manage ment, vol.43, SAGE journals, United States, 2016, pp. 561-593.DOI: https://doi.org/10.1177/1059601 116653911.

[20] Crant, J. Proactive behavior in organizations. Proce edings of the Journal of Management, vol.26, SAG E journals, United States, 2000, pp. 435-462.DOI: https://doi.org/10.1177/014920630002600304.

[21] Li, W.D., Fay, D., Frese, M., et al. Reciprocal relati onship between proactive personality and work cha racteristics: a latent change score approach . Procee dings of the J Appl Psychol, vol.99, APA Psyc Arti cles, United States, 2014, pp. 948-965.DOI: https:// doi.org/10.1037/a0036169.

[22] Jaiswal, N.K., Dhar, R.L. The influence of servant leadership, trust in leader and thriving on employee creativity. Proceedings of the Leadership \& Organ ization Development Journal, vol.38, Emerald, The United Kingdom, 2017, pp. 2-21.DOI: https://doi.o rg/10.1108/LODJ-02-2015-0017.

[23] Li Lu, Ye Baojuan, Yang Qiang et al. Authentic lea dership and employee voice behavior: Moderated mediating effect. Proceedings of the Chinese Journ al of Clinical Psychology, vol.04, 2019, pp.822-82 4+651(In Chinese)

[24] Li Chaoping, Mao Kaixian. The dynamic bidirectio nal mechanism of service-oriented leadership influ encing thriving at work. Proceedings of the Advanc es in Psychological Science, vol.26, 2018, pp.1734 -1748(In Chinese)

[25] Walumbwa, F.O., Muchiri, M.K., Wu, C., et al. Fir ed up to perform A multilevel examination of antec edents and consequences of thriving at work. Proce edings of the Academy of Management, vol.1, 201 6, pp.56-62.DOI: https://doi.org/10.5465/ambpp.20 16.79

[26] Wang Rong. Ethical leaders and subordinates' well -being at work and organizational citizenship beha vior. Proceedings of the Chinese Journal of Clinica 1 Psychology, vol.25, 2017, pp. 939-942+948. (In C hinese)

[27] Bandura, A. Social cognitive theory: An agentic pe rspective. Proceedings of the Annual review of psy chology, vol.52, 2001, pp.1-26. DOI: https://doi,or g/10.1146/annurev.psych.52.1.1

[28] Sonenshein, S., Dutton, J.E., Grant, A.M., et al. Gr owing at Work: Employees' Interpretations of Prog ressive Self-Change in Organizations. Proceedings of the Organization Science, vol. 24 NFORMS 201 3, pp. 552-570.DOI: https://doi.org/10.1287/orsc.1 120.0749

[29] Han Ji, Wei Wenwen. Review and prospect of rese arch on employee thriving at work. Proceedings of the Foreign Economics and Management, vol.35, 2 013, pp.46-53. (In Chinese)

[30] Kahn, W.A. Psychological conditions of personal e ngagement and disengagement at work. Proceeding $\mathrm{s}$ of the Academy of management journal, vol.33, $\mathrm{S}$ pringer, Berlin, Heidelberg 1990, pp. 692-724.DOI : https://doi.org/10.5465/256287

[31] Brown, S.P., Westbrook, R.A., Challagalla, G. Goo $\mathrm{d}$ cope, bad cope: adaptive and maladaptive coping strategies following a critical negative work event. Proceedings of the Journal of applied psychology, vol.90, APA Psyc Articles, United States, 2005, pp . 792-798.DOI: https://doi.org/10.1037/0021-9010. 90.4 .792

[32] Rothbard, N.P. Enriching or Depleting? The Dyna mics of Engagement in Work and Family Roles. Pr oceedings of the Administrative Science Quarterly, vol.46, JSTOR, 2001, pp. 655-684.DOI: https://do i.org/10.2307/3094827

[33] Druskat, V.U., Pescosolido, A.T. The content of eff ective teamwork mental models in self-managing $\mathrm{t}$ eams: Ownership, learning and heedful interrelatin g. Proceedings of the Human Relations, vol.55, SA GE journals, United States ,2002, pp. 283-314.DOI : https://doi.org/10.1177/0018726702553001

[34] Kark, R., Carmeli, A. Alive and creating: The medi ating role of vitality and aliveness in the relationshi $\mathrm{p}$ between psychological safety and creative work $\mathrm{i}$ nvolvement. Proceedings of the Journal of Organiz ational Behavior: The International Journal of Indu 
strial, Occupational and Organizational Psychology and Behavior, vol.30, WILEY, United States New York City ,2009, pp. 785-804. DOI: https://doi.org /10.1002/job.571

[35] Atwater, L., Carmeli, A. Leader-member exchange , feelings of energy, and involvement in creative w ork. Proceedings of the The Leadership Quarterly, vol.20, ELSEVIER, Netherlands ,2009, pp. 264-27 5.DOI: https://doi.org/10.1016/j.leaqua.2007.07.00 9

[36] Carmeli, A., Ben-Hador, B., Waldman, D.A.,et al. How leaders cultivate social capital and nurture em ployee vigor: Implications for job performance. Pro ceedings of the Journal of Applied Psychology, vol .94, APA Psyc Articles, United States ,2009, pp. 15 53-1561.DOI: https://doi.org/10.1037/a0016429

[37] Daniel, S.R.,Jordan, M.E. Measuring heedful interr elating in collaborative educational settings . Proce edings of the International Journal of School \& Edu cational Psychology, vol.3, Taylor Francis Online, 2015, pp. 25-36.DOI:https://doi.org/10.1080/21683 603.2014 .909342

[38] Carmeli, A., Spreitzer, G.M. Trust, connectivity, an $\mathrm{d}$ thriving: Implications for innovative behaviors at work. Proceedings of The Journal of Creative Beh avior, vol.43, WILEY, United States, New York Ci ty, 2009, pp. 169-191.DOI: https://doi.org/10.1002 /j.2162-6057.2009.tb01313.x

[39] Schmidt, J., Keil, T. What makes a resource valuab le? Identifying the drivers of firm-idiosyncratic res ource value. Proceedings of the Academy of Mana gement Review, vol.38, Springer, Berlin, Heidelber g, 2013, pp. 206-228.DOI: https://doi.org/10.5465/ amr.2010.0404

[40] Halbesleben, J.R., Neveu, J.-P., Paustian-Underdah 1, S.C., et al. Getting to the "COR": understanding the role of resources in conservation of resources th eory. Proceedings of the Journal of Management, $\mathrm{v}$ ol.40, SAGE journals, US, 2014, pp. 1334-1364.D OI: https://doi.org/10.1177/0149206314527130

[41] Boies, K., Fiset, J., Gill, H. Communication and tru st are key: Unlocking the relationship between lead ership and team performance and creativity. Procee dings of The Leadership Quarterly, vol.26, ELSEV IER, Netherlands, 2015, pp. 1080-1094.DOI: https: //doi.org/10.1016/j.leaqua.2015.07.007

[42] Zhang, A.Y., Tsui, A.S., Song, L.J., et al. How do I trust thee? The employee-organization relationship , supervisory support, and middle manager trust in $\mathrm{t}$ he organization. Proceedings of the Human Resour ce Management, vol.47, WILEY, United States, 20
08, pp. 111-132. DOI: https://doi.org/10.1002/hrm .20200

[43] Bono, J.E., Foldes, H.J., Vinson, G., et al. Workpla ce emotions: The role of supervision and leadership . Proceedings of the Journal of Applied Psychology , vol.92, APA Psyc Articles, United States, 2007, p p. 1357-1367.DOI: https://doi.org/10.1037/0021-9 010.92.5.1357

[44] Brower, H.H., Schoorman, F.D., Tan, H.H. A mod el of relational leadership: The integration of trust a nd leader-member exchange. Proceedings of The $\mathrm{L}$ eadership Quarterly, vol.11, 2000, pp. 227-250.

[45] Hobfoll, S.E. Conservation of resources: A new att empt at conceptualizing stress. Proceedings of the American psychologist, vol.44, APA Psyc Articles, United States ,1989, pp. 513-524.DOI: https://doi. org/10.1037/0003-066x.44.3.513

[46] Hobfoll, S.E., Johnson, R.J., Ennis, N., et al. Resou rce loss, resource gain, and emotional outcomes am ong inner city women. Proceedings of the Journal o f personality and social psychology, vol.84, APA P syc Articles, United States, 2003, pp. 632-643.DOI : https://doi.org/10.1037/0022-3514.84.3.632

[47] Brouer, R.L., Gallagher, V.C., Badawy, R.L. Abilit $y$ to Manage Resources in the Impression Manage ment Process: The Mediating Effects of Resources on Job Performance. Proceedings of the Journal of Business and Psychology, vol. 31, Springer Berlin, Heidelberg,2015, pp. 515-531.DOI: https://doi.org /10.1007/s10869-015-9426-5

[48] Hochwarter, W.A., Laird, M.D.,Brouer, R.L. Board Up the Windows: The Interactive Effects of Hurric ane-Induced Job Stress and Perceived Resources o $\mathrm{n}$ Work Outcomes . Proceedings of the Journal of Management, vol.34, SAGE journals, US, 2007 ,pp . 263-289..DOI: https://doi.org/10.1177/014920630 7309264

[49] Dalal, R.S., Sheng, Z. When is helping behavior un helpful? A conceptual analysis and research agenda . Proceedings of the Journal of Vocational Behavio r, vol.110, ELSEVIER, Netherlands, 2019, pp. 272 -285.DOI: https://doi.org/10.1016/j.jvb.2018.11.00 9

[50] Frieder, R.E., Hochwarter, W.A., DeOrtentiis, P.S. Attenuating the negative effects of abusive supervi sion: The role of proactive voice behavior and reso urce management ability. Proceedings of The Lead ership Quarterly, vol.26, ELSEVIER, Netherlands, 2015, pp.821-837. DOI: https://doi.org/10.1016/j.le aqua.2015.06.001 
[51] Parker, S.K., Williams, H.M., Turner, N. Modellin $\mathrm{g}$ the antecedents of proactive behavior at work. $\mathrm{Pr}$ oceedings of the Journal of Applied Psychology, vo 1. 91, APA Psyc Articles, United States, 2006, pp. 6 36-652.DOI: https://doi.org/10.1037/0021-9010.91 .3 .636

[52] Rothbard, N.P. Enriching or Depleting? The Dyna mics of Engagement in Work and Family Roles. Pr oceedings of the Administrative Science Quarterly, vol.46, JSTOR, 2001, pp. 655.DOI: https://doi.org $/ 10.2307 / 3094827$

[53] Daniel, S.R.,Jordan, M.E. Measuring heedful interr elating in collaborative educational settings . Proce edings of the International Journal of School \& Edu cational Psychology, vol.3, Taylor Francis Online, 2015, pp. 25-36.DOI: https://doi.org/10.1080/2168 3603.2014 .909342

[54] Hochwarter, W.A., Perrewe, P.L., Meurs, J.A., et a 1. The interactive effects of work-induced guilt and ability to manage resources on job and life satisfact ion. Proceedings of the Journal of Occupational He alth Psychol, vol.12, APA Psyc Articles, United St ates, 2007, pp. 125-135.DOI: https://doi.org/10.103 7/1076-8998.12.2.125

[55] Porath, C., Spreitzer, G., Gibson, C., et al. Thriving at work: Toward its measurement, construct valida tion, and theoretical refinement . Proceedings of th e Journal of Organizational Behavior, vol.33, WIL EY, United States, New York City, 2012, pp. 250-2 75.DOI: https://doi.org/10.1002/job.756.

[56] Anderson, N.R., West, M.A. Measuring climate for work group innovation: development and validatio $\mathrm{n}$ of the team climate inventory. Proceedings of the Journal of Organizational Behavior: The Internatio nal Journal of Industrial, Occupational and Organiz ational Psychology and Behavior, vol.19, WILEY, United States, New

[57] York City, 1998, pp. 235-258.DOI: https://doi.org/ 10.1002/(sici)1099-1379(199805)19:3<235::aid-jo b837>3.0.co;2-c. 